SANTOS JCS; SIQUEIRA WJ; MELO PCT; COLARICCIO A; LOURENÇÃO AL; MELO AMT. 2015. Selection of tomato breeding lines with resistance to Tomato yellow vein streak virus. Horticultura Brasileira 33: 345-351. DOI: http://dx.doi.org/10.1590/S0102053620150000300011

\title{
Selection of tomato breeding lines with resistance to Tomato yellow vein streak virus
}

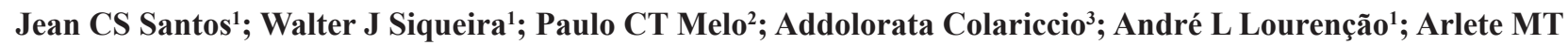 \\ Melo ${ }^{1}$ \\ 1'Instituto Agronômico, IAC-APTA, Campinas-SP, Brasil; jsantos.mt@hotmail.com; walterjs@iac.sp.gov.br; andre@iac.sp.gov.br; \\ arlete@iac.sp.gov.br; ${ }^{2}$ Universidade de São Paulo, USP-ESALQ, Dep. Prod. Vegetal, Piracicaba-SP, Brasil; paulomelo@usp.br; ${ }^{3}$ Instituto \\ Biológico, São Paulo-SP, Brasil; colariccio@biologico.sp.gov.br
}

\begin{abstract}
The study aimed to assess the reaction to Tomato yellow vein streak virus (ToYVSV) of determinate-growth tomato breeding lines of the Instituto Agronomico de Campinas (Campinas Agronomic Institute) germplasm collection and to select resistant plants. The experiment was carried out from August 2008 to February 2009 in greenhouse conditions. The geminivirus isolate used was collected in a tomato commercial field, in Sumaré, São Paulo State, Brazil. The experimental design was completely ramdomized blocks, with 25 treatments, four replications, and 30-plant plots. Virus transmission was carried out in cages containing viruliferous whiteflies (Bemisia tabaci $\mathrm{B}$ biotype). Plant reaction to the pathogen was evaluated by means of the percentage of symptomless plants 40, 50, 57 and 64 days after transplanting. Virus detection in each genotype was carried out using PCR. Although all genotypes showed plants with and without ToYVSV symptoms, lines IAC-TG 17 and LA 462 (Solanum peruvianum) stood out due to the highest percentage of symptomless plants in the four evaluation dates. Therefore, considering the genotypes evaluated and the edaphoclimatic conditions in which this work was carried out, lines IAC-TG 17 and LA 462 can be used as sources of resistance to ToYVSV.
\end{abstract}

Keywords: Solanum lycopersicum, Bemisia tabaci B biotype, begomovirus, vegetable breeding, genetic resistance.

\section{RESUMO}

Seleção de progênies de tomateiro resistentes a Tomato yellow vein streak vírus

Objetivou-se avaliar progênies de tomateiro de porte determinado da coleção biológica do Instituto Agronômico quanto à reação a Tomato yellow vein streak virus (ToYVSV) e selecionar plantas resistentes. A pesquisa foi conduzida em ambiente protegido, de $08 / 2008$ a $02 / 2009$. O isolado utilizado foi coletado em lavoura comercial de tomate de mesa, em Sumaré-SP. O delineamento experimental foi de blocos ao acaso, com 25 tratamentos, quatro repetições e 30 plantas por parcela. A transmissão do vírus foi feita em gaiolas contendo moscas-brancas virulíferas (Bemisia tabaci biótipo B). A reação das plantas ao patógeno foi avaliada pela porcentagem de plantas sem sintomas, aos 40, 50, 57 e 64 dias após o transplantio. Para a detecção do vírus em cada genótipo utilizou-se reação de PCR. Em todos os genótipos avaliados foram observadas plantas com e sem sintomas do ToYVSV. Entre esses genótipos, destacaram-se IAC-TG 17 e o acesso LA 462 (Solanum peruvianum) com as maiores porcentagens de plantas sem sintomas nas quatro épocas de avaliação. Considerando os genótipos utilizados e as condições edafoclimáticas de desenvolvimento da pesquisa, IAC-TG 17 e LA 462 podem ser utilizados como fontes de resistência ao ToYVSV.

Palavras-chave: Solanum lycopersicum, Bemisia tabaci biótipo $\mathrm{B}$, begomovírus, melhoramento de hortaliças, resistência genética.

\section{(Recebido para publicação em 24 de abril de 2014; aceito em 10 de dezembro de 2014)}

(Received on April 24, 2014; accepted on December 10, 2014)

$\mathrm{T}_{\mathrm{i}}$ omato (Solanum lycopersicum), is one of the most commonly grown vegetables in Brazil, second only to potato. Tomatoes are socioeconomically very important, with fields present throughout the country, especially in the Southeast and CentralWest regions.

In 2013, the world production of fresh and industrial tomato summed up 163.9 million $\mathrm{t}$, in a growing area of 4.7 million hectares, resulting in an average yield of $34.7 \mathrm{t} / \mathrm{ha}$. Brazil ranked eigth among the largest tomato growing countries in the world. China is the largest grower, harvesting 50.6 million $\mathrm{t}$ in 984.6 thousand ha, with an average yield of $51.4 \mathrm{t} / \mathrm{ha}$ (FAOSTAT, 2015). In 2014, Brazil produced 4.3 million $t$, in 65.2 thousand ha. From this total, $67.4 \%$ represent fresh market tomatoes, while the remaining $32.6 \%$ are tomato for industrial processing. The average Brazilian yields for fresh and processing tomatoes were 60.2 and 82.0 t/ha, respectively. Goiás, São Paulo, and Minas Gerais are the Brazilian states with the largest shares of the national production, $23.9,19.8$, and $15.7 \%$, respectively (IBGE, 2015).

Many pathogens lead to yield drops in tomatoes, particularly viruses. Among these, those belonging to the genus Begomovirus are a major concern. More than 180 species have already been reported, of which at least 50 can infect 
tomato (Brown et al., 2011). These viruses belong to the Geminiviridae family and have the whitefly Bemisia tabaci as their vector.

In the 1990s, Faria et al. (1997) found a new species of begomovirus in Campinas, São Paulo State, which infected the Santa Clara type tomato, resulting in losses from 19 to $70 \%$. This new species was named Tomato yellow vein streak virus (ToYVSV) (Faria et al., 1997). Colariccio et al. (2007) reported the occurrence of Tomato rugose mosaic virus (ToRMV) and ToYVSV in tomato producing regions in the state of São Paulo. Rocha et al. (2010) runned DNA molecular analysis on tomato samples collected in São Paulo and detected mixed infections of ToYVSV and Tomato severe rugose virus (ToSRV).

Genetic resistance is the most effective measure to control geminiviruses. According to Faria et al. (2000), sources of resistance to begomoviruses occuring in Brazil can be identified in other tomato species, but in S. lycopersicum. As these begomoviruses differ from the species that prevail in Europe, sources of resistance to a given geminivirus are not universally applicable, thus hindering the breeding process.

This study tested the hypothesis that resistance to ToYVSV is present in tomato lines of the Campinas Agronomic Institute (IAC) (Instituto Agronômico de Campinas) breeding program. Thus, the objectives were (1) to assess the reaction to Tomato yellow vein streak virus (ToYVSV) of determinate-growth lines from the IAC germplasm collection and (2) to select resistant plants.

\section{MATERIAL AND METHODS}

The research was carried out under greenhouse at the Center for Vegetable Crops (Centro de Horticultura) of the Campinas Agronomic Institute (Instituto Agronômico de Campinas), in Campinas, São Paulo State, Brazil (22 $54^{\prime} \mathrm{S}, 4^{\circ} 05^{\prime} \mathrm{W}, 674 \mathrm{~m}$ asl), from August 14, 2008, to February 04, 2009.

Experimental material - 20 determinate-growth tomato breeding lines from the IAC biological collection were used (Table 1). These lines were evaluated and selected for resistance to tospovirus (Tomato spotted wilt virus, TSWV) and begomovirus (ToYVSV) in IAC in previous years (Lourenção et al., 1997, 2004, 2005; Matos et al., 2003), under natural pressure, at the IAC Experimental Station, in Campinas.

The commercial hybrid Dominador and the wild accessions PI 134417 (S. habrochaites syn. Lycopersicon hirsutum), LA 462 (S. peruvianum syn. L. peruvianum), and PI 126931 (S. pimpinellifolium syn. L. pimpinellifolium) were used as the reference standards for resistance. Conversely, the commercial hybrid Alambra was used as the susceptibility standard. Despite of the indeterminate growth habit, hybrids Dominador and Alambra were chosen for being the leading cultivars when this study was carried out.

Source, maintenance and molecular characterization of the ToYVSV isolate - The ToYVSV isolate used in this work was collected in a fresh tomato commercial field in Sumaré, São Paulo State and was also used by Della Vecchia et al. (2007) and Santos (2009). The isolate was kept in tomato plants grown under air-conditioned conditions, exposed to a whitefly population infected with ToYVSV, at the experimental station of the Nunhems do Brasil Sementes Ltda., in Paulínia, São Paulo State. PCR and nucleotide sequence analysis of part of the viral DNA-A, including AV1 and AC3 genes, confirmed the pathogen identity (Figure 1A) (Della Vecchia et al., 2007). Total DNA was extracted from plants with typical ToYVSV symptoms. For running PCR, two pair of degenerate oligonucleotides, namely AV494

(5'-GCCYTRTAYAGRAAGCCMAG-3') / AC 1048

(5'-GGRTTDGARGCATGHGTACATG-3'), and PBL1v2040

(5'-GCCTCTGCAGCARTGRTCKATCTTCATACA-3') PCRc1

(5'-CTAGCTGCAGCATATTTACRARWATGCCA-3') were used. This pair amplifies fragments of about $576 \mathrm{bp}$ of DNA A, which corresponds to the protein coat gene, and 500 to 650 bp of DNA B, respectively (Edwards et al., 1991).

Sequencing was carried out on an ABI Prism 377 DNA Sequencer ${ }^{\mathrm{TM}}$ and the sequences were aligned using program CAP 3 to produce the final consensus sequence for the region involving genes AV1 (protein coat) and AC3 (Ren) of DNA A. The consensus sequence was blasted against other begomovirus sequences deposited in GenBank, National Center for Biotechnology Information (NCBI) (http://www.ncbi.nlm.nih.gov). The consensus sequence was finally aligned using the program Multalin (INRA) (http://prodes.toulouse.inra.fr/multalin/ multalin.html), while program Translate (http://ca.expasy.org/tools/dna.html) was used to produce the amino acid putative sequence, which was also compared to those available in GenBank.

Pathogen transmission - Seeds were sown in 200-cell polystyrene trays, filled with the commercial substrate Plantmax ${ }^{\mathrm{TM}}$, in August 14, 2008. Seedlings were watered weekly with a fertilization solution $(1 \mathrm{~g} / \mathrm{L})$ of calcium nitrate and potassium sulfate.

Upon the setting of the second pair of leaves, seedlings were inoculated with ToYVSV using infected $B$. tabaci $\mathrm{B}$ biotype adults. Seedlings were kept at $28^{\circ} \mathrm{C}$ and $60 \%$ of relative humidity for seven days and were shaken twice a day to induce the whitefly movement, contributing to an effective and uniform virus transmission. Seedlings were treated with bactericide solution to avoid possible bacterial infection.

Planting was carried out on September 9, 2008, at the 3-4 leaf stage, in greenhouse conditions. A high density planting system was used, spacing plants and lines with $45 \times 20 \mathrm{~cm}$, respectively. Whiteflies were controlled only 37 days after transplanting (DAT), allowing an extensive multiplication and, therefore, a high inoculum pressure.

Planting fertilization and top dressing were carried out according to the soil analysis through weekly fertirrigation via drip irrigation.

Resistance evaluation - To evaluate plant resistance to ToYVSV, the experiment was set in a completely randomized blocks design, with 25 treatments, namely 20 breeding lines and five controls, and four replications, in 30-plant plots. Plant reaction to ToYVSV was evaluated phenotypically, 
using the absence or presence of symptoms as indication of resistance or susceptibility, respectively. Evaluations were performed 40, 50, 57, and 64 DAT, by counting the symptomless plants. Data were converted into percentage. Plants with symptoms were discarded in every evaluation. To calculate the percentage of symptomless plants, the total number of plants in all four evaluations was considered. The following symptoms were considered as indication of disease: leaf chlorosis, leaflet yellowing, vein clearing, roughness, and reduction in plant size (Nizio, 2008).

Based on the results, genotypes were classified in five resistance levels, according to the Tripathi \& Varma (2002) recommendation with modifications, as follows: 90 to $100 \%$ of symptomless plants (highly resistant); 70 to $89.9 \%$ (resistant); 50 to $69.9 \%$ (moderately resistant); 20 to $49.9 \%$ (susceptible), and 0 to $19.9 \%$ (highly susceptible).

ToYVSV detection - Total DNA was extracted (Dellaporta et al., 1983) from leaf tissue collected 96 DAT in infected genotypes and used in PCR. Leaf fragments were ground in liquid nitrogen, followed by maceration in $600 \mu \mathrm{L}$ of extraction buffer $2 \%$ CTAB (2\% CTAB, $100 \mathrm{mM}$ Tris. HCL, 20 mM EDTA, $\mathrm{pH}$ 8.0). The mixture was homogenized and placed in a water bath with moderate stirring for $30^{\prime}$ at $65^{\circ} \mathrm{C}$. Then, $600 \mu \mathrm{L}$ of chloroform/isoamyl alcohol were added; the suspension was mixed by inversion and centrifuged at $7500 \mathrm{~g}$ for $5^{\prime}$ at $4^{\circ} \mathrm{C}$. Following, $40 \mu \mathrm{L}$ of $\mathrm{CTAB} / \mathrm{NaCl}$ solution were added to the upper phase, which was mixed by inversion again. In sequence, $500 \mu \mathrm{L}$ of chloroform/isoamyl alcohol were added, the suspension was mixed by inversion and centrifuged at $7500 \mathrm{~g}$ for $5^{\prime}$ at $4^{\circ} \mathrm{C}$. Next, $400 \mu \mathrm{L}$ of CTAB precipitation solution (1\% CTAB, $50 \mathrm{mM}$ Tris.HCl, $10 \mathrm{mM}$ EDTA, pH 8.0) were added. Tubes were mixed by inversion and placed in a waterbath at $65^{\circ} \mathrm{C}$ for $30^{\prime}$, followed by centrifugation at $500 \mathrm{~g}$ for $5^{\prime}$ at $4^{\circ} \mathrm{C}$. Once the upper phase was discarded, $500 \mu \mathrm{L}$ of HighSaltTE solution were added to the remaining material. After mixing by inversion, 300 $\mu \mathrm{L}$ of isopropanol were added, followed by new mixing and centrifugation at
$7500 \mathrm{~g}$, for $10^{\prime}$ at $4^{\circ} \mathrm{C}$. After disposing the upper phase, $500 \mu \mathrm{L}$ of $70 \%$ alcohol were added and the suspension was centrifuged at $10,000 \mathrm{~g}$ for $10^{\prime}$ at $4^{\circ} \mathrm{C}$. The alcohol was discarded and the tubes were dried in a sample concentrator (Eppendorf ${ }^{\mathrm{TM}}$ Concentrator 5301) for 15'. The DNA obtained was suspended in $40 \mu \mathrm{L}$ of sterile distilled deionized water.

PCR - For the amplification of viral DNA from total plant DNA, the GoTaq ${ }^{\mathrm{TM}}$ DNA Polymerase kit (PROMEGA) was used. For PCR, the universal primers [PAL1v1978 (5,

GCATCTGCAGGCCCACATYGTCTTYCCNGT $\left.3^{\prime}\right)$ and PAR1c496 (5'

AATACTGCAGGGCTTYCTRTACATRGG

3')] (Rojas et al., 1993) were used.

The reaction was carried out in a PTC100 thermocycler (MJ Research), at $94^{\circ} \mathrm{C}$ for $2^{\prime}, 40$ cycles of $94^{\circ} \mathrm{C}$ for 1 ', $50^{\circ} \mathrm{C}$ for $1^{\prime}, 72^{\circ} \mathrm{C}$ for $3^{\prime}, 72^{\circ} \mathrm{C}$ for $10^{\prime}$, and stored at $4^{\circ} \mathrm{C}$ until further use. The amplified DNA fragments, ranging from 1200 to $1600 \mathrm{bp}$, were analyzed on $1.5 \%$ agarose gel in TAE buffer (Tris-AcetateEDTA) containing ethidium bromide $(1 \mu \mathrm{g} / \mathrm{L})$.

Statistical Analysis - Data were submitted to analysis of variance using the software Genes (Cruz, 2010). Means were compared by the Scott-Knott test $(p<0.05)$. The coefficient of genotypic determination $\left(\mathrm{R}^{2}\right)$ was also calculated.

\section{RESULTS AND DISCUSSION}

In the first evaluation, 40 days after transplanting (DAT), there were significant differences among genotypes: two clusters, with three resistance classes (Tripathi \& Varma, 2002), were formed. Fourteen genotypes were highly resistant to ToYVSV. Among them, 12 IAC breeding lines stood out, showing from 90.0 to $96.7 \%$ of symptomless plants (Table 2).

In the second evaluation, 50 DAT, four clusters came out, with genotypes falling into three resistance classes, namely resistant, moderately resistant, and susceptible. No genotypes remained as highly resistant. Among the resistant ones, the symptomless plants ranged from 70.0 to $83.3 \%$. The breeding lines
IAC-TG 10, IAC-TG 13, IAC-TG 17, and IAC-TG 19 stood out (Table 2).

In the third evaluation, 57 DAT, the breeding lines IAC-TG 10, IAC-TG 17, and IAC-TG 19 were moderately resistant, along with the check genotypes Dominador, LA 462, and PI 134417, with 51.7 to $67.5 \%$ of symptomless plants. Lines IAC-TG 17 and IAC-TG 19 and the accession LA 462 remained as the most resistant. The control genotype PI 126931, initially used as reference for resistance, was classified as susceptible, as well as the control Alambra, as expected (Table 2).

In the fourth and last evaluation, 64 DAT, genotypes were grouped in five clusters. The line IAC-TG 17 and the control LA 462 did not differ significantly from each other and were moderately resistant, with 50.8 and $54.2 \%$ of symptomless plants, respectively. Nevertheless, both genotypes differed from the controls Dominador, PI 134417, and PI 126931, used as resistance standards (Table 2).

Not all plants had symptoms up to 50 DAT, since the virus needs appropriate conditions for replication within the cells. In addition, the expression of symptoms is environment-dependent in the course of plant development. It must be considered also, that accessions LA 462 and PI 126931 did not show resistance of the antixenosis-type (nonpreference) to B. tabaci B biotype in this work, in agreement with Oriani et al. (2011). Interesting enough, accession PI 134417 was currently susceptible to begomovirus, with only $46 \%$ of symptomless plants (Table 2 ), while in the work of Oriani et al. (2011), it is reported as nonpreferred for oviposition. However, under the high insect population pressure applied up to 37 DAT, disease progressed substantially, as expressed by the large drop in the percentage of symptomless plants from 40 DAT $(93.5 \%)$ to 64 DAT (46\%). This result highlights the need of evaluating plants for extended periods. In evaluations carried out very soon after the inoculation period, susceptible plants may present few mild symptoms or even no symptoms at all. From the breeding perspective, the genotypes of interest are those that remain symptomless until 
Table 1. Determinate-growth tomato breeding lines and experimental controls evaluated for the reaction to ToYVSV (progênies experimentais de tomate de porte determinado e testemunhas avaliadas quanto à reação a ToYVSV). Campinas, IAC, 2009.

\begin{tabular}{|c|c|c|}
\hline Genotype & Description & Genealogy \\
\hline IAC-TG 1 & SVS-ML-1-1-1-1-1-1 & breeding lines Asgrow Seed Co. \\
\hline IAC-TG 2 & SVS-ML-1-1-1-1-1-2 & breeding lines Asgrow Seed Co. \\
\hline IAC-TG 3 & IAC S4-3-18C(1-1-1-18+10)-1 & (Stevens x IPA-6) x IPA-6 \\
\hline IAC-TG 4 & IAC S4-3-18C(1-1-1-18+10)-2 & (Stevens x IPA-6) x IPA-6 \\
\hline IAC-TG 5 & IAC S4-3-18C(1-1-1-18+10)-3 & (Stevens x IPA-6) x IPA-6 \\
\hline IAC-TG 6 & $\mathrm{~F}_{9}$ TySw5 (1+3)-1-1 & breeding lines Asgrow Seed Co. \\
\hline IAC-TG 7 & $\mathrm{~F}_{9}$ TySw5 (1+3)-1-2 & breeding lines Asgrow Seed Co. \\
\hline IAC-TG 8 & $\mathrm{~F}_{9}$ TySw5 $(1+3)-1-3$ & breeding lines Asgrow Seed Co. \\
\hline IAC-TG 9 & $\mathrm{~F}_{9}$ TySw5 $(1+3)-1-4$ & breeding lines Asgrow Seed Co. \\
\hline IAC-TG 10 & IAC 2/98 X TySw5-1-5-1-1 & S. Clara x breeding line Asgrow Seed Co. \\
\hline IAC-TG 11 & IAC 2/98 X TySw5-1-5-1-2 & breeding lines Asgrow Seed Co. \\
\hline IAC-TG 12 & IAC 2/98 X TySw5-1-5-1-3 & breeding lines Asgrow Seed Co. \\
\hline IAC-TG 13 & IAC 2/98 X TySw5-1-5-1-4 & breeding lines Asgrow Seed Co. \\
\hline IAC-TG 14 & IAC 2/98 X TySw5-1-5-2-1 & breeding lines Asgrow Seed Co. \\
\hline IAC-TG 15 & IAC 2/98 X TySw5-1-5-2-2 & breeding lines Asgrow Seed Co. \\
\hline IAC-TG 16 & IAC 2/98 X TySw5-1-5-2-3 & breeding lines Asgrow Seed Co. \\
\hline IAC-TG 17 & IAC $14-2-49$ & Angela x LA 462 \\
\hline IAC-TG 18 & $\mathrm{~F}_{9}$ TySw5 (1+3)-3 & breeding line Asgrow Seed Co. \\
\hline IAC-TG 19 & IAC 2/98 X TySw5-1-2-3 & S. Clara $x$ breeding line Asgrow Seed Co. \\
\hline IAC-TG 20 & IAC 2/98 X TySw5-1-2 & breeding lines Asgrow Seed Co. \\
\hline \multicolumn{2}{|c|}{ Control genotypes } & Sources \\
\hline \multicolumn{2}{|c|}{ Alambra } & Clause Vegetable Seeds \\
\hline \multicolumn{2}{|c|}{ Dominador } & Agristar \\
\hline \multicolumn{2}{|c|}{ PI 134417 (S. habrochaites) } & BAG IAC \\
\hline \multicolumn{2}{|c|}{ LA 462 (S. peruvianum) } & BAG IAC \\
\hline \multicolumn{2}{|c|}{ PI 126931 (S. pimpinellifolium) } & BAG IAC \\
\hline
\end{tabular}

fruit production.

No dwarf plants were observed up to 64 DAT. Contrary to the usual in most begomovirus studies, the decision to extend evaluations up to that date was taken to avoid missing late symptom manifestation due to virus latency in apparently healthy plants. Genotype PI 134417 was one of these cases, since susceptibility appeared only 64 DAT, while genotype Alambra showed symptoms 57 DAT, confirming the susceptibility in the next evaluation, 64 DAT (Table 2). Moreover, there might also be confounding situations between mis-inoculation and partial resistance or virus latency when plants within the breeding line are genotypically different, which again stresses the importance of extending evaluations over time to reliably confirm the resistance or susceptible status.
In a breeding perspective, there might be interesting differences between lines or among plants within lines with some level of partial resistance in the stage of late infection and late severity. Thus, symptoms that were not noticed in the first evaluations may show up in the following ones. Plants with delayed cell colonization due to any adult resistance mechanism are important for breeding. To farmers, late infection may result in reduction in crop losses. Considering that the genotypes currently studied are progenies in initial generations, therefore not yet in homozygosis, nor genetically stabilized, segregation is expected. Such a likely variability, combined with partial resistance, may result in a range of distinct reactions to the virus inoculation. Drops in the percentage of symptomless plants over time may come from variations in virus titrations.

During the experiment, conditions were so appropriate for the whitefly infestation that the wild introduction PI 126931, so far considered resistant to begomovirus (Pilowsky \& Cohen, 1974), turned out to be susceptible, although this unexpected reaction was observed only 57 DAT. Nevertheless, there were plants that remained symptomless even after 64 DAT. Those were selected and will be used in future crosses, for progeny evaluation.

Considering the four evaluations, IAC-TG 17 stood out as the most resistant progeny to ToYVSV. IACTG 17 comes from an interspecific cross between $S$. lycopersicum and $S$. peruvianum. In the research conducted by Matos et al. (2003), this progeny (named IAC 14-2) had the highest resistance reaction index to the same 
Table 2. Percentage of symptomless plants, rating of resistance to ToYVSV 40, 50, 57, and 64 days after transplanting (DAT) and joint analysis of four evaluation dates in determinategrowth tomato breeding lines [porcentagem de plantas sem sintomas, classificação da resistência a ToYVSV 40, 50, 57 e 64 dias após o transplantio (DAT) e análise conjunta das quatro épocas, em progênies de tomateiro de porte determinado]. Campinas, IAC, 2009.

\begin{tabular}{|c|c|c|c|c|c|c|c|c|}
\hline Genotype & 40 DAT & $\mathbf{R R}$ & 50 DAT & $\mathbf{R R}$ & 57 DAT & $\mathbf{R R}$ & 64 DAT & $\mathbf{R R}$ \\
\hline IAC-TG 17 & $96.7 \mathrm{a}$ & HR & $83.3 \mathrm{a}$ & $\mathrm{R}$ & $66.7 \mathrm{a}$ & MR & $50.8 \mathrm{a}$ & MR \\
\hline IAC-TG 9 & $96.7 \mathrm{a}$ & HR & $66.7 \mathrm{~b}$ & MR & $40.0 \mathrm{c}$ & $\mathrm{S}$ & $19.2 \mathrm{~d}$ & HS \\
\hline IAC-TG 20 & $95.0 \mathrm{a}$ & HR & $67.5 \mathrm{~b}$ & MR & $42.5 \mathrm{c}$ & S & $23.3 \mathrm{c}$ & S \\
\hline IAC-TG 10 & $94.2 \mathrm{a}$ & HR & $78.3 \mathrm{a}$ & $\mathrm{R}$ & $51.7 \mathrm{~b}$ & MR & $27.5 \mathrm{c}$ & S \\
\hline Alambra & $94.2 \mathrm{a}$ & HR & $67.5 \mathrm{~b}$ & MR & $38.3 \mathrm{c}$ & $\mathrm{S}$ & $15.8 \mathrm{e}$ & HS \\
\hline PI 126931 & $93.3 \mathrm{a}$ & HR & $56.7 \mathrm{c}$ & MR & $25.8 \mathrm{~d}$ & S & $08.3 \mathrm{e}$ & HS \\
\hline IAC-TG 13 & $93.3 \mathrm{a}$ & HR & $74.2 \mathrm{a}$ & $\mathrm{R}$ & $47.5 \mathrm{~b}$ & S & $25.8 \mathrm{c}$ & S \\
\hline IAC-TG 15 & $93.3 \mathrm{a}$ & HR & $65.8 \mathrm{~b}$ & MR & $39.2 \mathrm{c}$ & S & $20.8 \mathrm{~d}$ & S \\
\hline IAC-TG 4 & $92.5 \mathrm{a}$ & HR & $59.2 \mathrm{c}$ & MR & $35.0 \mathrm{c}$ & S & $20.0 \mathrm{~d}$ & S \\
\hline IAC-TG 18 & $92.5 \mathrm{a}$ & HR & $68.3 \mathrm{~b}$ & MR & $44.2 \mathrm{c}$ & S & $25.8 \mathrm{c}$ & S \\
\hline PI 134417 & $92.5 \mathrm{a}$ & HR & $65.0 \mathrm{~b}$ & MR & $52.5 \mathrm{~b}$ & MR & $46.0 \mathrm{~b}$ & S \\
\hline IAC-TG 19 & $90.8 \mathrm{a}$ & HR & $80.0 \mathrm{a}$ & $\mathrm{R}$ & $60.0 \mathrm{a}$ & MR & $36.7 \mathrm{~b}$ & S \\
\hline IAC-TG 5 & $90.0 \mathrm{a}$ & HR & $62.5 \mathrm{~b}$ & MR & $39.2 \mathrm{c}$ & S & $25.8 \mathrm{c}$ & S \\
\hline IAC-TG 7 & $90.0 \mathrm{a}$ & HR & $57.5 \mathrm{c}$ & MR & $37.5 \mathrm{c}$ & S & $20.8 \mathrm{~d}$ & S \\
\hline IAC-TG 12 & $89.2 \mathrm{a}$ & $\mathrm{R}$ & $60.0 \mathrm{c}$ & MR & $35.0 \mathrm{c}$ & S & $21.0 \mathrm{~d}$ & S \\
\hline IAC-TG 14 & $87.5 \mathrm{a}$ & $\mathrm{R}$ & $61.7 \mathrm{~b}$ & MR & $42.5 \mathrm{c}$ & S & $29.2 \mathrm{c}$ & $\mathrm{S}$ \\
\hline IAC-TG 8 & $86.7 \mathrm{a}$ & $\mathrm{R}$ & $64.2 \mathrm{~b}$ & MR & $39.2 \mathrm{c}$ & S & $18.3 \mathrm{~d}$ & HS \\
\hline IAC-TG 6 & $86.7 \mathrm{a}$ & $\mathrm{R}$ & $66.7 \mathrm{~b}$ & MR & $44.2 \mathrm{c}$ & $\mathrm{S}$ & $25.0 \mathrm{c}$ & $\mathrm{S}$ \\
\hline Dominador & $82.5 \mathrm{~b}$ & $\mathrm{R}$ & $70.0 \mathrm{~b}$ & $\mathrm{R}$ & $55.8 \mathrm{~b}$ & MR & $43.3 \mathrm{~b}$ & S \\
\hline LA 462 & $79.2 \mathrm{~b}$ & $\mathrm{R}$ & $78.3 \mathrm{a}$ & $\mathrm{R}$ & $67.5 \mathrm{a}$ & MR & $54.2 \mathrm{a}$ & MR \\
\hline IAC-TG 1 & $79.2 \mathrm{~b}$ & $\mathrm{R}$ & $50.0 \mathrm{~d}$ & MR & $29.2 \mathrm{~d}$ & $\mathrm{~S}$ & $12.4 \mathrm{e}$ & HS \\
\hline IAC-TG 16 & $76.7 \mathrm{~b}$ & $\mathrm{R}$ & $58.3 \mathrm{c}$ & MR & $35.8 \mathrm{c}$ & $\mathrm{S}$ & $20.0 \mathrm{~d}$ & $\mathrm{~S}$ \\
\hline IAC-TG 11 & $75.8 \mathrm{~b}$ & $\mathrm{R}$ & $40.0 \mathrm{~d}$ & $\mathrm{~S}$ & $19.2 \mathrm{~d}$ & HS & $10.8 \mathrm{e}$ & HS \\
\hline IAC-TG 3 & $71.7 \mathrm{~b}$ & $\mathrm{R}$ & $38.3 \mathrm{~d}$ & S & $20.0 \mathrm{~d}$ & $\mathrm{~S}$ & $13.3 \mathrm{e}$ & HS \\
\hline IAC-TG 2 & $65.0 \mathrm{~b}$ & MR & $45.8 \mathrm{~d}$ & $\mathrm{~S}$ & $30.0 \mathrm{~d}$ & $\mathrm{~S}$ & $15.8 \mathrm{e}$ & $\mathrm{HS}$ \\
\hline CV (\%) & 9.7 & & 14.5 & & 17.2 & & 22.3 & \\
\hline $\mathrm{R}^{2}(\%)$ & 74.4 & & 83.9 & & 91.8 & & 94.8 & \\
\hline
\end{tabular}

Means followed by same letter in columns do not differ significantly from each other, ScottKnott test, $\mathrm{p}<0.05$ (médias seguidas de mesma letra na coluna não diferem significativamente entre si pelo teste de Scott-Knott, $\mathrm{p}<0,05)$; $R R=$ resistance rating (classificação da resistência), where (onde): $\mathrm{HR}=$ highly resistant (altamente resistente); $\mathrm{R}=$ resistant (resistente); $\mathrm{MR}=$ moderately resistant (moderadamente resistente); $\mathrm{S}=$ susceptible (suscetível); HS= highly susceptible (altamente suscetível).

virus. Moreover, it has also resistance to tospovirus and to the tomato leafminer (Tuta absoluta) (Lourenção et al., 1984, 1997).

Surprisingly, PI 126931 was highly susceptible to the ToYVSV isolate presently used. Pilowsky \& Cohen (1974) identified resistance to Tomato yellow leaf curl virus (TYLCV) in lines of this accession and reported different inheritance models controlling the resistance, such as incomplete monogenic, dominant monogenic and recorded by Lapidot et al. (2001), the combination of different begomoviruses and Lycopersicon species suggests that the genetic control of resistance depends on the combination between host genotype and virus species.

It is important to note that in the current work the disease evaluation criterium was qualitative, meaning that the lack of symptoms of infection by ToYVSV was taken as resistance. Matos et al. (2003) state that this is a straightforward evaluation, since distinguishing between plants with or without symptoms is rather easy. Nevertheless, such evaluation does not record differences in levels of resistance that might come from the barriers to geminivirus replication and movement within the cell.

High $\mathrm{R}^{2}$ values were obtained in all evaluation dates: $74.4 \%$ 40 DAT, $83.9 \%$ 50 DAT, $91.8 \% 57$ DAT, and $94.8 \% 64$ DAT (Table 2). High $\mathrm{R}^{2}$ values point to little environment influence over the trait expression. According to Raizer \& Vencovsky (1999), coefficients of determination higher than $80 \%$ represent low data dispersion, indicating high reliability on the environmental response, and are used as orientation to explain the genotype behavior in a given environment.

It cannot be stated that the resistance expressed by genotype Dominador is due to gene $T y-1$. However, so far Ty-1 has been the most frequently used gene in breeding for resistance to geminivirus, especially in Europe. Gene Ty- 1 provides partial resistance against different begomovirus species (Santana et al., 2001; Matos et al., 2003; Boiteux et al., 2007).

Several authors faced differences and variability in disease symptomatology similar to those observed in the current research. Zakay et al. (1991) searched for sources of resistance to TYLCV, the prevailing species in Europe and Middle East and, as observed in this work, one of the most challenging difficulties for selecting resistance sources was the variation in symptom severity. It was observed that symptoms were milder in wild species than in commercial genotypes.

New sproutings, with mild ToYVSV 


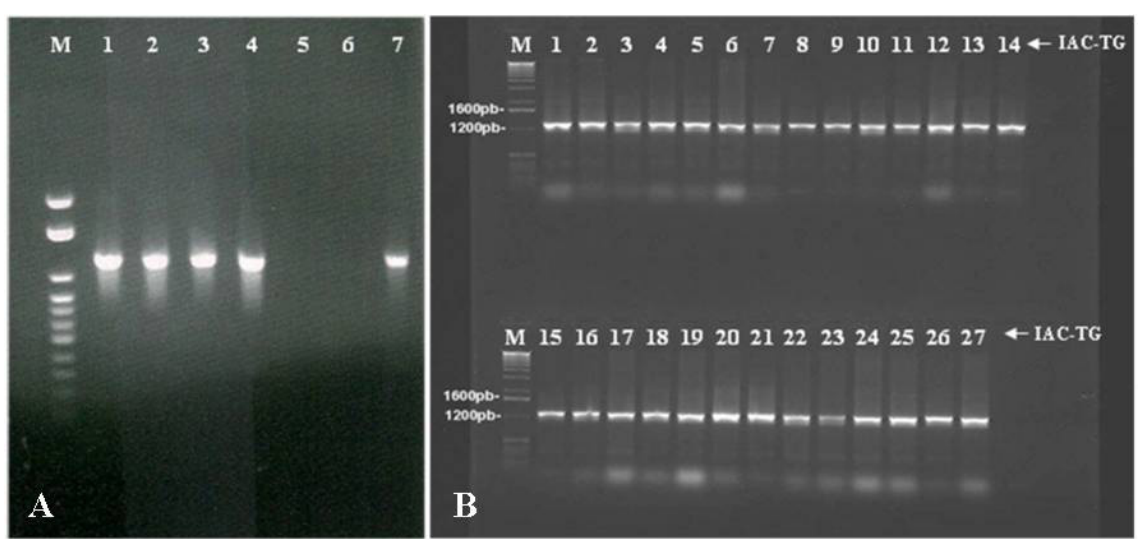

Figure 1. (A) Identification of ToYVSV by PCR (identificação de ToYVSV por PCR), M= marker (marcador); $1=$ resistant sample (amostra resistente); $2=$ evaluated sample (amostra avaliada); $3=$ symptomless sample (amostra sem sintoma); $4=$ sample with symptoms (amostra com sintoma); $5=$ negative control, healthy tomato plant (controle negativo, tomateiro sadio); $6=$ PCR control (controle PCR); $7=$ positive control, tomato plant infected by ToYVSV (controle positivo, tomateiro infectado por ToYVSV); (B) Viral detection by PCR with universal primers for Begomovirus, breeding lines IAC-TG, 1 to 20 (detecção viral por PCR com oligonucleotídeos universais para Begomovirus, progênies da série IAC-TG, 1 a 20); 21= $\mathrm{F}_{1}$ Alambra, susceptible experimental control ( $\mathrm{F}_{1}$ Alambra, testemunha suscetível); 22 to $24=$ resistant experimental controls, respectively, $\mathrm{F}_{1}$ Dominador, PI 134417 (S. habrochaites), and LA 462 (S. peruvianum) [testemunhas resistentes, respectivamente, $\mathrm{F}_{1}$ Dominador, PI 134417 e 24 LA 462]; 25= IAC-TG 19 symptomless sample (amostra assintomática de IAC-TG 19); 26= symptomless sample of $\mathrm{F}_{1}$ Dominador (amostra assintomática do $\mathrm{F}_{1}$ Dominador); $27=$ standard sample (amostra padrão), $\mathrm{M}=$ marker (marcador). Bands indicate DNA fragments between 1200 and 1500 base pairs (as bandas indicam fragmentos amplificados de DNA entre 1200 e 1500 pares de bases). Campinas, IAC, 2009.

symptoms, were also noticed in this work, especially in more resistant genotypes. These sprouts were not considered on the evaluations carried out 57 and 64 DAT, since more severe symptoms were present in the still abundant older branches. Nizio (2008), evaluating the resistance of experimental hybrids to begomovirus in a grafting experiment, observed that symptom severity tended to decrease in most of the genotypes along time. This finding was explained by the development of new sprouts with mild symptoms further away from the grafting point. It is likely that allele $T y-1$ interferes with the viral protein responsible for the virus circulation within the plant (Michelson et al., 1994), impairing the movement of viral particles to the new sprouts (Nizio, 2008).

Results of geminivirus detection by PCR are shown in Figure 1B. Two symptomless samples, from line IACTG 19 and $F_{1}$ Dominador, were also tested. All samples, including those from symptomless plants, proved positive for ToYVSV, confirming the plant infection with the pathogen, in spite of the lack of symptoms.

The progeny IAC-TG 17 showed the best performance when it comes to resistance to the isolate of ToYVSV currently tested, and it may be used in further studies. Although its fruits do not meet commercial standards, the absence of resistance sources within the cultivated tomato, and the combined resistance to TSWV and ToYVSV found in this progeny (Lourenção et al., 1997, 2004, 2005), turns IAC-TG 17 into a valuable genotype for tomato breeding.

Considering the genotypes tested and the edafoclimatic conditions in which this work was carried out, the current results indicated that the line IAC-TG 17 and the accession LA 462 can be used as sources of resistance to ToYVSV.

\section{ACKNOWLEDGEMENTS}

To CAPES (Coordination for the Improvement of Higher Education Personnel) for granting a master's degree scolarship to the first author. To CNPq (The National Council for Scientific and Technological Development) for the grant in Productivity in Research awarded to the second and fourth authors, and for the grant in Productivity in Technological Development and Innovative Extension awarded to the last author.

\section{REFERENCES}

BOITEUX LS; OLIVEIRA VR; SILVA CH; MAKISHIMA N; INOUE-NAGATA AK; FONSECA MEN; GIORDANO LB. 2007. Reaction of tomato hybrids carrying the Ty-1 locus to Brazilian bipartite Begomovirus species. Horticultura Brasileira 25: 20-23.

BROWN J; FAUQUET CM; BRIDDON R; ZERBINI FM; MORIONES E; NAVASCASTILLO J. 2011. Family Geminiviridae. In: KING AMQ; LEFKOWITZ E; ADAMS MJ; CARSTENS EB (eds). Virus Taxonomy. Ninth Report of the International Committee on Taxonomy of Viruses. London: Elsevier Academic Press, p.351-373.

COLARICCIO A; EIRAS M; CHAVES ALR; BERGMAN JC; ZERBINI FM; HARAKAVA R; CHAGAS CM. 2007. Tomato yellow vein streak virus, a new Begomovirus on tomato from Brazil: complete DNA A sequence and some molecular and biological features. Journal of Plant Pathology 89: 385-390.

CRUZ CD. 2010, 4 de janeiro. Programa Genes - versão Windows. Aplicatico computacional em genética e estatística. Disponível em http:// www.ufv.br/dbg/genes/Genes_Br.htm.

DELLA VECCHIA MGS; ROSA DD; BERGAMIN FILHO A; AMORIM L; REZENDE JAM; RIBEIROA. 2007. Dinâmica temporal e espacial da begomovirose causada por Tomato yellow vein streak virus em tomateiro na região de Campinas-SP. Summa Phytopathologica 33: 387-395.

DELLAPORTA SL; WOOD J; HICKS JB. 1983. A plant minipreparation: version II. Plant Molecular Biology Report 1: 19-20.

EDWARDS K; JOHNSTON C; THOMPSON C. 1991. A simple and rapid method for the preparation of plant genomic DNA for PCR analysis. Nucleic Acid Research 19: 1349.

FAOSTAT - FAO Statistics Division. 2012, 4 de julho. Disponível em http://faostat3.fao.org/ faostat-gateway/go/to/home/E.

FARIA JC; BEZERRA IC; ZERBINI FM; RIBEIRO SG; LIMA MF. 2000. Situação atual das geminiviroses no Brasil. Fitopatologia Brasileira 25: 25-137.

FARIA JC; SOUZA-DIAS JAC; SLACK SA; MAXWELL DP. 1997. A new geminivirus associated with tomato in the State of São Paulo, Brazil. Plant Disease 81: 423.

HANSON PM; BERNACCHI D; GREEN S; TANKSLEY SD; MUNIYAPPA V; PADMAJA 
AS; MEI CH; KUO G; FANG D; TZU CJ. 2000. Mapping a wild tomato introgression associated with Tomato yellow leaf curl virus resistance in a cultivated tomato line. Journal of the American Society for Horticultural Science 125: 15-20.

IBGE - Instituto Brasileiro de Geografia e Estatística. 2013, 6 de outubro. Levantamento sistemático da produção agrícola. 2011. Disponível em http://www.ibge.gov.br/home/ estatistica/indicadores/agropecuaria/lspa/ lspa 201111.pdf

KASRAWI MA; SUWWAN MA; MANSOURA. 1988. Sources of resistance do Tomato yellow leaf curl virus (TYLCV) in Lycopersicon species. Euphytica 37: 61-64.

LAPIDOT M; FRIEDMANN M; PILOWSKY M; BEN-JOSEPH R; COHEN S. 2001. Effect of host plant resistance to Tomato yellow leaf curl virus (TYLCV) on acquisition and transmission by its whitefly vector. Phytopathology 91: 1209-1213.

LOURENÇÃO AL; MELO AMT; SIQUEIRA WJ; COLARICCIO A; MELO PCT. 2004. Avaliação da resistência de acessos de tomateiro a tospovírus e a geminivírus. Horticultura Brasileira 22: 193-196.

LOURENÇÃO AL; NAGAI H; SIQUEIRA WJ; USBERTI FILHO JA; MELO AMT. 1997. Seleção de tomateiros resistentes a tospovírus. Bragantia 56: 21-31.

LOURENÇÃO AL; NAGAI H; ZULLO MAT. 1984. Fontes de resistência a Scrobipalpula absoluta em tomateiro. Bragantia 43: 569-577.
LOURENÇÃO AL; SIQUEIRA WJ; MELOAMT; PALAZZO SRL; MELO PCT; COLARICCIO A. 2005. Resistência de cultivares e linhagens de tomateiros a Tomato chlorotic spot virus e a Potato virus Y. Fitopatologia Brasileira 30: 619-614.

MATOS ES; SIQUEIRA W; LOURENÇÃO A; MELO AMT; SAWAZAKI H; SOUZADIAS J; COLARICCIO A. 2003. Resistência de genótipos de tomateiro a um isolado de geminivírus do cinturão verde de Campinas, São Paulo. Fitopatologia Brasileira 28: 159-165.

MICHELSON I; ZAMIR D; CZOSNEK H. 1994. Accumulation and translocation of Tomato yellow leaf curl virus (TYLCV) in a Lycopersicon esculentum breeding line 69 containing the L. chilense TYLCV tolerance gene Ty-1. Phytopathology 84: 928-933.

NIZIO DAC. 2008. Capacidade combinatória de linhagens avançadas de tomateiro de mesa e seleção assistida por marcadores moleculares para resistência a begomovírus e tospovírus. Lavras: UFLA. 71p (Dissertação mestrado).

ORIANI MAG; VENDRAMIM JD; VASCONCELOS CJ. 2011. No-choice ovipositional preference of Bemisia tabaci (Gennadius) B biotype on tomato genotypes. Scientia Agricola 68: 147-153.

PILOWSKY M; COHEN S. 1974. Inheritance of resistance to Tomato yellow leaf curl virus in tomatoes. Phytopathology 64: 632-635.

RAIZER AJ; VENCOVSKY R. 1999. Estabilidade fenotípica de novas variedades de cana-de-açúcar para o Estado de São Paulo. Pesquisa Agropecuária Brasileira 34: 2241-2246.

ROCHA KCG; MARUBAYASHI JM; NAVASCASTILLO J; PAVAN MA; KRAUSESAKATE R. 2010. Ocorrência e variabilidade genética do Tomato severe rugose virus em tomateiro e pimentão no Estado de São Paulo. Summa Phytopathologica 36: 222-227.

ROJAS MR; GILBERTSON RL; RUSSELL DR; MAXWELL DP. 1993. Use of degenerate primers in the polymerase chain reaction to detect whitefly-transmitted geminiviruses. Plant Disease 77: 340-347.

SANTANA FM; RIBEIRO SG; MOITA AW; MOREIRA JUNIOR DJ; GIORDANO LB. 2001. Sources of resistance in Lycopersicon spp. to a bipartite whitefly-transmitted geminivirus from Brazil. Euphytica 122: 45-51.

SANTOS FFB. 2009. Obtenção e seleção de híbridos de tomate visando à resistência ao Tomato yellow vein streak virus (ToYVSV). Campinas: IAC. 86p. (Dissertação mestrado).

TRIPATHI S; VARMA A. 2002. Identification of sources of resistance in Lycopersicon species to Tomato leaf curl geminivirus (ToLCV) by agroinoculation. Euphytica 129: 43-54.

ZAKAY Y; ZEIDAN M; KEDAR N; RABINOVITCH H; CZOSNEK H; ZAMIR D. 1991. Screening Lycopersicon accessions for resistance to Tomato yellow leaf curl virus presence of viral DNA and symptom development. Plant Disease 75: 279-281. 